\title{
Body size of commom opossum Didelphis aurita Wied-Neuwied 1826 (Didelphimorphia: Didelphidae) on southern brazilian islands
}

\author{
Salvador, CH.*, Graipel, ME. and Simões-Lopes, PC. \\ Departamento de Ecologia e Zoologia, Centro de Ciências Biológicas, \\ Campus da Universidade Federal de Santa Catarina - UFSC, \\ Trindade, CP 5102, CEP 88010-970, Florianopolis, SC, Brazil \\ *e-mail: carloshsalvador@hotmail.com
}

Received December 12, 2006 - Accepted July 18, 2007 - Distributed May 31, 2009

(With 1 figure)

\begin{abstract}
The body size of vertebrates isolated on islands can undergo changes due to ecological features of these environments. This study aimed to compare the body size of the common opossum, Didelphis aurita, from different insular populations within the same archipelago in southern Brazil. The opossum populations showed corporal variation and different hypotheses were raised to understand the results. This study constitutes the most detailed body size comparison of a marsupial within different insular populations in the Neotropical zone and the data gathered represents an initial contribution for regional fauna biometric knowledge.
\end{abstract}

Keywords: archipelago, Atlantic Rainforest, biometry, insular population, sexual dimorphism.

\section{Tamanho corpóreo de gambás Didelphis aurita Wied-Neuwied 1826 (Didelphimorphia: Didelphidae) em ilhas no sul do Brasil}

\begin{abstract}
Resumo
O tamanho corpóreo de vertebrados isolados em ilhas pode sofrer alterações em função das particularidades ecológicas desses ambientes. O presente trabalho comparou o tamanho corpóreo de gambás, Didelphis aurita, em ilhas costeiras de um mesmo arquipélago no Sul do Brasil e encontrou diferenças de tamanho entre as localidades. Os gambás apresentaram variações para as medidas corporais e diferentes hipóteses foram consideradas para entender os resultados. Esta é a comparação mais detalhada de tamanho corpóreo entre populações insulares de um marsupial neotropical e uma contribuição inicial para o conhecimento da biometria da fauna regional.
\end{abstract}

Palavras-chave: arquipélago, biometria, dimorfismo sexual, Mata Atlântica, população insular.

\section{Introduction}

Insular environments have a significant effect on animals (Foster, 1964) and body size changes of vertebrates on islands have been the subject of interest and discussion in the evolutionary and ecological literature (Foster, 1964; Grant, 1965; Fall 1970; Van Valen, 1973; Case, 1978; Heany, 1978; Wassersug et al., 1979; Lawlor, 1982; Lomolino, 1985; Angerbjorn, 1985; Damuth, 1993; Demetrius, 2000; Clegg and Owns, 2002; Cassey and Blackburn, 2004; Meiri et al., 2004; Millien and Damuth, 2004; Meiri et al., 2005; Lomolino, 2005). However, for the Neotropical fauna, no work has been dedicated to the comparison of body size between insular vertebrate populations.

Marsupials represent $9.1 \%$ of all mammals species in the Atlantic Rainforest (Fonseca et al., 1996) and the common opossums, genus Didelphis Linné 1758 (Didelphidae), are the largest and most widely distributed, being present throughout the Neotropical Region (Gardner, 1973; Emmos, 1990). They also play a major

role in the small mammal community structure (Fonseca and Robinson, 1990; Fonseca, 1991; Graipel et al., 2006) as well as in parasite-host interaction (Linardi, 2006).

Therefore, their body size can be influenced by insularity, i.e. the ecological and evolutionary consequences of being isolated in a poor biota environment (Foster, 1964). The ecological features of islands, such as reduced or enhanced food availability according to island area, a low level of predation, reduced inter-species competition, have been reported as the main islands features affecting insular mammal body size changes (Foster, 1964; Case, 1978; Heany, 1978; Lawlor, 1982; Lomolino, 1985; 2005). Lomolino (2005) defends the existence of a pattern for such change, known as the Island Rule, but he draws attention to the pattern's geography scale-dependence in such a way that variation in island characteristics (i.e. those within archipelagos), like size and isolation, may account for much of the total variation in body size of insular vertebrates. 
Nevertheless, biometric information on Didelphis is restricted to general studies (e.g., Gardner, 1973; Tyndale-Biscoe and Mackenzie, 1976; Fonseca and Kierluff, 1989; Catzeflis et al., 1997; Cerqueira and Lemos, 2000) with little data being available on insular species (Cherem et al., 1996) or comparisons between populations (Cáceres and Monteiro-Filho, 1999). Even so, the few studies which have compared body size among Didelphis populations have contributed to some ecological understanding of this genus (Cáceres and Monteiro-Filho, 1999).

The objective of this study was to compare the body size of the common opossum, D. aurita Wied-Neuwied 1826, within an archipelago.

\section{Material and Methods}

\subsection{Study site}

Four ecological populations of common opossums in different insular environments were sampled between 1996 and 2002: Arvoredo Island, Ratones Grande Island and a peri-urban and a forest area on Santa Catarina Island (Figure 1). All sites lie within a warm tropical climate zone covered by Atlantic Rainforest. The islands belong to the same archipelago which was likely to have been formed around 7,000-9,000 years ago through the sea level rising in this region (see Correa, 1996).

The 45,100 ha of Santa Catarina Island makes it the second biggest on the coast of Santa Catarina State, southern Brazil, located between the parallels $27^{\circ} 25^{\prime}$ and $27^{\circ} 75^{\prime} \mathrm{S}$ and the meridians $48^{\circ} 20^{\prime}$ and $48^{\circ} 40^{\prime} \mathrm{W}$. The shortest distance from the continent is $500 \mathrm{~m}$ (Caruso,

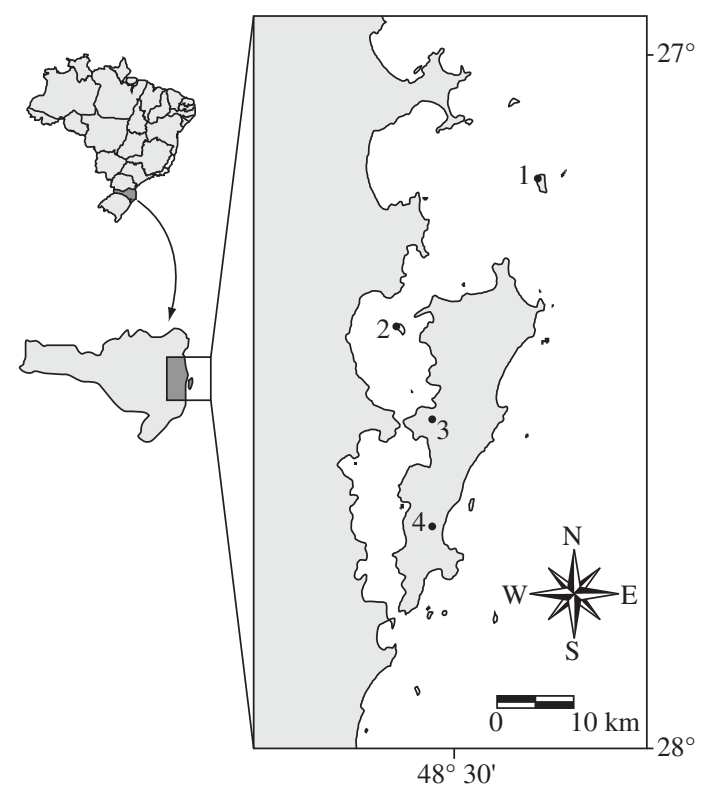

Figure 1. 1) Arvoredo Island, 2) Ratones Grande Island, 3) the peri-urban and 4) forest area on Santa Catarina Island off the state of Santa Catarina coast, southern Brazil.
1990). One of the sample areas on this island is surrounded by a high-density human population under the direct influence of urbanization (Graipel and SantosFilho, 2006). The other one is located in the Lagoa do Peri Municipal Park surrounded by primary and secondary forest, where all the 25 species of non-volant terrestrial mammals registered on the island (Graipel et al., 2001 ; 2006) are likely to be found.

Arvoredo Island $\left(27^{\circ} 17^{\prime} 42^{\prime \prime} \mathrm{S}\right.$ and $\left.48^{\circ} 21^{\prime} 48^{\prime \prime} \mathrm{W}\right)$ has an area of $270 \mathrm{ha}, 10 \mathrm{~km}$ north of Santa Catarina Island and $25 \mathrm{~km}$ east of the continent. There are natural freshwater sources and the occurrence of one other non-volant terrestrial mammal, the wild rice mouse Oligoryzomys sp. The deepest water between the mainland and Arvoredo Island is around $30 \mathrm{~m}$.

Ratones Grande Island (27 $7^{\circ} 9^{\prime} 30^{\prime \prime} \mathrm{S}$ and $\left.48^{\circ} 36^{\prime} 42^{\prime \prime} \mathrm{W}\right)$ has an area of 19.4 ha, and lies at a distance of $3 \mathrm{~km}$ and $1 \mathrm{~km}$ from the continent and Santa Catarina Island, respectively. There are no natural freshwater sources (Cherem et al., 1996) and the common opossum and Neotropical otter (Lontra longicaudis) are the only non-volant terrestrial mammal species on this island (Graipel et al., 1997).

\subsection{Methods}

The animals were caught with wire mesh live-traps $(18 \times 28 \times 40 \mathrm{~cm})$ placed on the ground, from two to four times per month, with a total effort of 1946 trap-nights. Baits were used (banana with peanut butter, bacon or fish).

The animals were sexed, aged, measured, weighed, marked and released at the same trap station, where they were captured. The body length (with head length), the tail, the ear and the hind foot (with and without nails) were measured following the recommendation of Emmons (1990). Combinations of holes in different positions of the ears were used to individually mark the animals (Monteiro-Filho and Abe, 1999).

Four age classes were defined by means of the identification of the eruption of the upper molars: infants, young, sub-adults and adults, with the first $\left(\mathrm{m}^{1}\right)$, second $\left(\mathrm{m}^{2}\right)$, third $\left(\mathrm{m}^{3}\right)$ and fourth $\left(\mathrm{m}^{4}\right)$ upper molars being visible, respectively (Graipel et al., 2006).

The body measurements used in the statistical analysis relate to the first catch of each adult individual $\left(\mathrm{m}^{4}\right)$. For each population, a Mann-Whitney U-test was used to compare the size between sexes (Zar, 1999). Due to confirmation of sexual dimorphism, separate analyses were carried out on each sex using the ANOVA F-test followed by the Bonferroni a priori test (Zar, 1999). The software BioEstat 3.0 was used for all statistical analysis and significant differences were considered as five percent or less, type I error probability (Ayres et al., 2003).

\section{Results}

The comparison shown that opossum body sizes of both sexes were different among populations for all corporal measurements (Tables 1 and 2), except for ear 
Table 1. Comparison of male body size of the common opossum Didelphis aurita for four ecological populations from different islands off the Santa Catarina State coast, southern Brazil: Arvoredo Island (AI), Ratones Grande Island (RGI) and two environments on Santa Catarina Island, a peri-urban (SCI-P) and a forest area (SCI-F), ANOVA F-test value (F) and type I error probability $(\mathrm{p})$.

\begin{tabular}{|c|c|c|c|c|c|c|}
\hline Measurement & Population site & Sample size & Mean* (mm) & Standard Deviation & $\mathbf{F}$ & $\mathbf{P}$ \\
\hline \multirow{4}{*}{$\begin{array}{l}\text { Body length } \\
\text { (without tail) }\end{array}$} & AI & 9 & $371.78 \mathrm{a}$ & 25.71 & 4.01 & 0.01 \\
\hline & SCI-P & 9 & $405.11 \mathrm{~b}$ & 24.14 & - & - \\
\hline & RGI & 24 & $373.29 \mathrm{a}$ & 22.29 & - & - \\
\hline & SCI-F & 14 & $370.21 \mathrm{a}$ & 33.42 & - & - \\
\hline \multirow[t]{4}{*}{ Tail length } & AI & 9 & $332.56 \mathrm{a}$ & 10.06 & 4.34 & 0.01 \\
\hline & SCI-P & 9 & $351.44 \mathrm{~b}$ & 31.13 & - & - \\
\hline & RGI & 24 & $325.83 \mathrm{a}$ & 12.15 & - & - \\
\hline & SCI-F & 14 & $330.00 \mathrm{a}$ & 20.63 & - & - \\
\hline \multirow[t]{4}{*}{ Ear length } & AI & 9 & $52.56 \mathrm{a}$ & 2.93 & 2.03 & 0.12 \\
\hline & SCI-P & 9 & $57.44 \mathrm{a}$ & 2.80 & - & - \\
\hline & RGI & 24 & $54.13 \mathrm{a}$ & 2.55 & - & - \\
\hline & SCI-F & 13 & $53.25 \mathrm{a}$ & 2.23 & - & - \\
\hline \multirow{4}{*}{$\begin{array}{l}\text { Length of hind } \\
\text { foot with nail }\end{array}$} & $\mathrm{AI}$ & 9 & $57.78 \mathrm{a}$ & 3.96 & 3.49 & 0.02 \\
\hline & SCI-P & 9 & $61.89 \mathrm{~b}$ & 1.96 & - & - \\
\hline & RGI & 24 & $58.92 \mathrm{a}$ & 2.50 & - & - \\
\hline & SCI-F & 14 & $58.57 \mathrm{a}$ & 3.39 & - & - \\
\hline \multirow{4}{*}{$\begin{array}{l}\text { Length of hind } \\
\text { foot without nail }\end{array}$} & AI & 9 & $52.56 \mathrm{a}$ & 3.47 & 5.91 & $<0.01$ \\
\hline & SCI-P & 9 & $57.44 \mathrm{~b}$ & 1.81 & - & - \\
\hline & RGI & 24 & $54.13 \mathrm{a}$ & 2.38 & - & - \\
\hline & SCI-F & 14 & $53.25 \mathrm{a}$ & 3.20 & - & - \\
\hline
\end{tabular}

*Averages followed by the same letters (a or b) are not significantly different (Bonferroni 5\%).

Table 2. Comparison of female body size of the common opossum Didelphis aurita for four ecological populations from different islands off the Santa Catarina State coast, southern Brazil: Arvoredo Island (AI), Ratones Grande Island (RGI) and two environments on Santa Catarina Island, a peri-urban (SCI-P) and a forest area (SCI-F), ANOVA F-test value (F) and type I error probability (p).

\begin{tabular}{|c|c|c|c|c|c|c|}
\hline Measurement & Population site & Sample size & $\operatorname{Mean} *(\mathbf{m m})$ & Standard Deviation & $\mathbf{F}$ & $\mathbf{P}$ \\
\hline \multirow{4}{*}{$\begin{array}{l}\text { Body length } \\
\text { (without tail) }\end{array}$} & AI & 15 & $353.73 \mathrm{a}$ & 35.97 & 3.47 & 0.02 \\
\hline & SCI-P & 25 & $369.52 \mathrm{~b}$ & 19.26 & - & - \\
\hline & RGI & 26 & $353.92 \mathrm{a}$ & 31.60 & - & - \\
\hline & SCI-F & 12 & $340.25 \mathrm{a}$ & 15.50 & - & - \\
\hline \multirow[t]{4}{*}{ Tail length } & AI & 15 & $353.60 \mathrm{a}$ & 25.18 & 11.58 & $<0.01$ \\
\hline & SCI-P & 25 & $345.08 \mathrm{a}$ & 21.61 & - & - \\
\hline & RGI & 26 & $324.04 \mathrm{~b}$ & 17.43 & - & - \\
\hline & SCI-F & 12 & $319.33 \mathrm{~b}$ & 12.13 & - & - \\
\hline \multirow[t]{4}{*}{ Ear length } & AI & 15 & $52.33 \mathrm{a}$ & 2.64 & 2.71 & 0.05 \\
\hline & SCI-P & 22 & $51.91 \mathrm{a}$ & 3.04 & - & - \\
\hline & RGI & 26 & $54.04 \mathrm{a}$ & 3.04 & - & - \\
\hline & SCI-F & 12 & $53.50 \mathrm{a}$ & 1.78 & - & - \\
\hline \multirow{4}{*}{$\begin{array}{l}\text { Length of hind } \\
\text { foot with nail }\end{array}$} & AI & 15 & $57.80 \mathrm{a}$ & 1.97 & 3.12 & 0.03 \\
\hline & SCI-P & 25 & $56.77 \mathrm{a}$ & 3.85 & - & - \\
\hline & RGI & 26 & $57.31 \mathrm{a}$ & 3.07 & - & - \\
\hline & SCI-F & 12 & $54.42 \mathrm{~b}$ & 2.71 & - & - \\
\hline \multirow{4}{*}{$\begin{array}{l}\text { Length of hind } \\
\text { foot without nail }\end{array}$} & AI & 15 & $52.87 \mathrm{a}$ & 2.23 & 3.27 & 0.03 \\
\hline & SCI-P & 22 & $52.68 \mathrm{a}$ & 4.41 & - & - \\
\hline & RGI & 26 & $52.23 \mathrm{a}$ & 3.04 & - & - \\
\hline & SCI-F & 12 & $49.33 \mathrm{~b}$ & 2.57 & - & - \\
\hline
\end{tabular}

*Averages followed by the same letters (a or b) are not significantly different (Bonferroni 5\%). 
length ( $p>0.05)$. Regarding this exception, the males from the peri-urban population of Santa Catarina Island were larger than the others for all corporeal measurements $(\mathrm{p}<0.05)$ (Table 1$)$. Similarly, the females from the peri-urban population showed a larger body length than the others $(p<0.05)$ in such a way that the females from the forest environment on this same island had body length as short as Arvoredo and Ratones island females $(p>0.05)$ and the shortest hind foot length $(p<0.05)$ (Table 1). The Arvoredo Island females had tails as long as females from the peri-urban population $(\mathrm{p}>0.05)$ and the Ratones Grande Island females showed an intermediate pattern with the tail as short as the smallest females (from the forest environment on Santa Catarina Island; $\mathrm{p}<0.05)$, but with hind foot length as long as the other ones $(\mathrm{p}>0.05)$ (Table 2).

When a significant difference between males and females was observed, the former were always larger, except for the tail length of individuals from Arvoredo Island, where the females had longer tails than the males $(\mathrm{p}<0.01)$. On Ratones Grande Island, the sexual differences were expressed in body length and size of hind food without nails $(\mathrm{p}<0.05)$. The population from the Santa Catarina Island forest showed sexual dimorphism for body length and size of hind foot with and without nails $(\mathrm{p}<0.05)$ (Table 3$)$.

\section{Discussion}

As expected for a vertebrate, there were variations of opossum body size among insular populations within an archipelago (Lomolino, 2005) and the reasons for such a change have been discussed elsewhere, regarding influences of resource availability (e.g., water supply) and the island's diversity (e.g., ecological release due to predators, competitor and parasite absence following Case, 1978; Heany, 1978; Lawlor, 1982; Angerbjörn, 1982 and Lomolino, 1985; 2005).

Except for the water contained on Bromeliacea, Ratones Grande Island has no fresh water available (Cherem et al., 1996; Graipel et al., 1997). The observed Gerivá-coconut pulp (Syagrus romanzoffiana) consumption by the opossums, much higher than on other islands (personal observation), was an indicator of a possible water stress. The consumption of fruit as a water source has also been reported for other mammals (Nagy and Milton, 1979) and water stress can reduce body growth, as observed in the case of the Amazonian Basin opossum (D. marsupialis) during the dry season (Telford-Jr. et al., 1979). The lack of fresh water on Ratones Grande Island can be, then, one of the factors associated with the opossum's smaller body size there, at least compared to the opossums from Arvoredo Island. Some similar body size between them was expected because they share the

Table 3. Comparison of body size between sexes of the common opossum Didelphis aurita for four populations from different islands off the Santa Catarina coast, southern Brazil: Arvoredo Island (AI), Ratones Grande Island (RGI) and two environments on Santa Catarina Island, a peri-urban (SCI-P) and a forest area (SCI-F), Mann-Whitney U-test [Z(U)] and type I error probability (p).

\begin{tabular}{|c|c|c|c|c|c|c|c|}
\hline \multirow[t]{2}{*}{ Measurement } & \multirow[t]{2}{*}{ Population site } & \multicolumn{2}{|c|}{ Sample size } & \multicolumn{2}{|c|}{ Mean $(\mathbf{m m})$} & \multirow[t]{2}{*}{$\mathbf{Z}(\mathbf{U})$} & \multirow[t]{2}{*}{ p } \\
\hline & & $\hat{0}$ & q & $\hat{0}$ & 우 & & \\
\hline \multirow{4}{*}{$\begin{array}{l}\text { Body length } \\
\text { (without tail) }\end{array}$} & $\mathrm{AI}$ & 9 & 15 & 371.78 & 353.73 & 1.13 & 0.26 \\
\hline & SCI-P & 9 & 25 & 405.11 & 369.52 & 3.40 & $<0.01$ \\
\hline & RGI & 24 & 26 & 373.29 & 353.92 & 2.69 & $<0.01$ \\
\hline & SCI-F & 14 & 12 & 370.21 & 340.25 & 2.55 & 0.01 \\
\hline \multirow[t]{4}{*}{ Tail length } & AI & 9 & 15 & 332.56 & 353.6 & 2.80 & $<0.01$ \\
\hline & SCI-P & 9 & 25 & 351.44 & 345.08 & 1.17 & 0.24 \\
\hline & RGI & 24 & 26 & 325.83 & 324.04 & 0.82 & 0.41 \\
\hline & SCI-F & 14 & 12 & 330 & 319.33 & 1.77 & 0.08 \\
\hline \multirow[t]{4}{*}{ Ear length } & AI & 9 & 15 & 52.56 & 52.33 & 0.09 & 0.93 \\
\hline & SCI-P & 9 & 22 & 57.44 & 51.91 & 170.00 & 0.09 \\
\hline & RGI & 24 & 26 & 54.13 & 54.04 & 0.69 & 0.49 \\
\hline & SCI-F & 13 & 12 & 53.25 & 53.50 & 0.73 & 0.47 \\
\hline \multirow{4}{*}{$\begin{array}{l}\text { Length of hind } \\
\text { foot with nail }\end{array}$} & AI & 9 & 15 & 57.78 & 57.80 & 0.03 & 0.98 \\
\hline & SCI-P & 9 & 25 & 61.89 & 56.77 & 3.16 & $<0.01$ \\
\hline & RGI & 24 & 26 & 58.92 & 57.31 & 1.83 & 0.07 \\
\hline & SCI-F & 14 & 12 & 58.57 & 54.42 & 2.46 & $<0.01$ \\
\hline \multirow{4}{*}{$\begin{array}{l}\text { Length of hind } \\
\text { foot without nail }\end{array}$} & AI & 9 & 15 & 52.56 & 52.87 & 0.24 & 0.81 \\
\hline & SCI-P & 9 & 22 & 57.44 & 52.68 & 3.13 & $<0.01$ \\
\hline & RGI & 24 & 26 & 54.13 & 52.23 & 2.31 & 0.02 \\
\hline & SCI-F & 14 & 12 & 53.25 & 49.33 & 2.88 & $<0.01$ \\
\hline
\end{tabular}


islands' main environmental characteristics for mammal corporal changes, i.e. island size and diversity (e.g., Heany, 1978; Lomolino, 2005). Comparing them with the Santa Catarina Island (45,100 ha) according to their size and diversity, Ratones Grande Island (19 ha) can be considered as small and as poor as Arvoredo Island (270 ha), both with two species of non-volant terrestrial mammals.

The Ratones Grande Island opossum body size can also be under negative pressure caused by hematophagous ectoparsites (Salvador et al., 2007) so that they can affect the host fitness through skin irritation and damage, disease infections and anaemia (Lehmann, 1992; Caughley and Sinclair, 1994) and they have reached the highest level of infestation on this island (Salvador et al., 2007). Rather, this infestation was the lowest in opossums from Arvoredo Island, where they are also free of their main competitors and predators. If such environmental features are involved somehow with insular vertebrate body change, the larger size of the Arvoredo Island opossum, compared to those from the forest environment of Santa Catarina Island, followed the expected (e.g., Lomolino, 2005), at least for three female corporal measurements, so that the biota in the latter is richer with the presence of many of the opossums' competitors and predators (Graipel et al., 2001; 2006).

The criterion established here for the data collection, considering as animal adults those with the last upper molar erupted, could include samples from individuals younger than one year old up to individuals of more than three years old (Cordero and Nicolas, 1987; Austad, 1993). In this way, variations in the age structure of the studied populations could make the results biased through the catching of mainly younger or older individuals. But only the peri-urban population has shown a considered variation in age structure. This happened due to the disappearance of sub-adult $\left(\mathrm{m}^{3}\right)$ individuals in this population in periods before the reproduction season caused by death or migration, and only male adults $\left(\mathrm{m}^{4}\right)$ were caught after this season, these showing features of advanced senescence (Graipel and SantosFilho, 2006), such as over worn teeth (see Cordero and Nicolas, 1987). Although a bias in the male age structure may have played a role in the comparison of body size population, leading to bigger body size in this population, the females of the peri-urban population also had a larger size than those of the other populations without signs of senescence. Therefore, there is no such bias for females and other factors must be affecting their larger size. With the present knowledge, however, it was not possible to identify these factors. There is no information about these opossums' ecology living in a human environment, such as diet, parasitism and how they deal with domestic dogs and cats as their main predators and competitors.

Some authors have reported no sexual dimorphism for Didelphis (Monteiro-Filho, 1987; Stallings, 1989), but it is common to find that at least some of the body measurements are larger in males than in females (e.g., Gardner, 1973; Tyndale-Biscoe and Mackenzie, 1976; Fonseca and Kierluff, 1989; Cherem et al., 1996; Catzeflis et al., 1997; Cáceres and Monteiro-Filho, 1999; Cerqueira and Lemos, 2000) as observed in this study. However, a variation in this pattern, such as the tail length of females from Arvoredo Island being longer than that of males, can occasionally occur. Cerqueira and Lemos (2000), for example, observed that out of 18 cranial measurements taken, one in D. aurita and two in D. marsupialis were greater in females than in males.

The lack of information makes difficult a detailed analyse about the causes of such body size variation. The genetic drift and founder effects, for example, can be considered as important as the ecological reasons to explain our observations. Barton (1996) notes the importance of founder effects which produce different results in terms of genetic drift, and this scenario is more plausible than the selective forces because the latter have not had enough time to change the frequency of the alleles. In the present case, it is not clear whether the opossum population from Arvoredo Island was either isolated together with the island, around 8,000 years ago when the sea level was $30 \mathrm{~m}$ lower than today (see Correa, 1996), or if the population is derived from a few founders that colonized the island recently. Also, it is not known whether the population suffered one or many bottleneck effects.

The common opossum showed variations in body size within the archipelago and these data constitute an initial contribution for opossum biometrics as well as insular mammals population knowledge in a Neotropical Region.

Acknowledgements - We thank the Federal Scientific Initiation Scholarship Program - PIBIC/CNPq/Federal University of Santa Catarina (UFSC) - and the Ecology and Zoology Department of the Biological Science Center (UFSC) which provided the undergraduate scholarships for the development of this work. Special thanks are also dedicated to Fernando Fernandez for reading and making comments on the original manuscript and to Shibean for the English language revision.

\section{References}

ANGERBJÖRN, A., 1985. The evolution of body size in mammals on islands: some comments. Amer. Nat., vol. 125, no. 2, p. 304-309.

AUSTAD, SN., 1993. Retarded senescence in an insular population of Virginia opossums (Didelphis virginiana). $J$. Zool., vol. 229, p. 69-708.

AYRES, M., AYRES, M., AYRES, DL. and SANTOS, AS., 2003. BioEstat 3.0: aplicação estatística nas áreas das ciências biológicas e médicas. 2 ed. Sociedade Civil Mamirauá, Belém. Brasília: Ministério da Ciência e Tecnologia.

BARTON, NH., 1996. Natural selection and random genetic drift as causes of evolution on islands. Phil. Trans. of The Roy. Soc. of Lond. (Series B, )., vol. 351, p. 785-795. 
CÁCERES, NC. and MONTEIRO-FILHO, ELA., 1999. Tamanho corporal em populações naturais de Didelphis (MAMMALIA-MARSUPIALIA) do Sul do Brasil. Braz. J. Biol. $=$ Rev. Bras. Biol., vol. 59, no. 3 p. 461-469.

CARUSO, ML., 1990. O desmatamento na Ilha de Santa Catarina de 1500 aos dias atuais. 2 ed. Florianópolis: Federal University of Santa Catarina Press.

CASE, TJ., 1978. A general explanation for body size trends in terrestrial vertebrates. Ecol., vol. 59, no. 1, p. 1-8.

CASSEY, P. and BLACKBURN, TM., 2004. Body size trends in a Holocene island bird assemblage. Ecograp., vol. 27, no. 1, p. $59-67$.

CATZEFLIS, FM., RICHARD-HANSEN, C., FOURNIERCHAMBRILLON, C., LAVERGNE, A. and VIÉ, J., 1997. Biométrie, reproduction et sympatrie chez Didelphis marsupialis et $D$. albiventris en Guyane française (Didelphidae: Mammalia). Mamm., vol. 61, no. 2, p. 231-243.

CAUGHLEY, G. and SINCLAIR, ARE., 1994. Wildlife ecology and management. Boston: Blackwell Scientific Publication.

CERQUEIRA, R., 1985. The distribution of Didelphis in South America (Polipromata, Didelphidae). Jour. of Biogeo., vol. 12, p. $135-145$.

CERQUEIRA, R. and LEMOS, B., 2000. Morphometric differentiation between Neotropical black-earned opossums, Didelphis marsupialis and D. auria (Didelphimorphia, Didelphidae). Jour. of Mammal., vol. 64, no. 3, p. 319-327.

CHEREM, JJ., GRAIPEL, ME., MENEZES, ME. and SOLDATELI, M., 1996. Observações da biologia do gambá (Didelphis aurita) na Ilha de Ratones Grande, Estado de Santa Catarina, Brasil. Biot., vol. 9, no. 2, p. 47-56.

CLEGG, SM. and OWENS, IPF., 2002. The 'island rule' in birds: medium body size and its ecological explanation. Proc. R. Soc. Lond. B, vol. 269, p. 1359-1365.

CORRÊA, ICS., 1996. Les variations du niveau de la mer durant les derniers 17.500 ans BP: l'exemple de la plate-forme continentale du Rio Grande do Sul-Brésil. Mar. Geol., vol. 130, p. $163-178$.

DAMUTH, J., 1993. Cope's rule, the island rule and the scaling of mammalian population density. Nat., vol. 365, p. 748- 750.

DEMETRIUS, L., 2000. Directionality theory and the evolution of body size. Proc. R. Soc. Lond. B, vol. 267, p. 2385-2391.

FALL, MW., 1970. Morphological variation of Peromyscus leucopus noveboracensis on the Bass islands of Lake Eire. Jour. of Mammal., vol. 51, no. 2, p. 370-372.

FONSECA, GAB., 1991. Muitas reservas pequenas: uma solução? Ciên. Hoje, vol. 76, no. 13, p. 18-19.

FONSECA, GAB. and KIERLUFF, MCM., 1989. Biology and natural history of Brazilian Atlantic Forest small mammals. Bull. of Flo. Sta. Mus., Biol. Scie., vol. 34, no. 3, p. 99-152.

FONSECA, GAB. and ROBINSON, JG., 1990. Forest size and structure: competitive and predatory effects on small mammal communities. Biol. Cons., vol. 53, p. 265-294.

FONSECA, GAB., HERMAN, G., LEITE, YLR., MITTERMEIER, RA., RYLANDS, AB. and PATTON, J.L., 1996. Lista anotada dos mamíferos brasileiros. Occa. Pap. in Cons. Bio., vol. 4, p. 1-38.
FOSTER, JB., 1964. The evolution of mammals on island. Nat., vol. 202, p. 234-235.

GARDNER, A., 1973. The systematics of the genus Didelphis (Marsupialis: Didelphidae) in North and Middle America. Spec. Publ. of the Mus. Tex. Tech Univer., vol. 4, p. 1-81.

1993. Order Didelphimorphia. In Wilson, DE. and REEDER, DM. (Org.). Mammals species of the world: A taxonomic and geografic reference. Washington: Smithsonian Institution. p. 15-23.

GRAIPEL, ME., CHEREM, JJ., MACHADO, DA., GARCIA, PC., MENEZES, ME. and SOLDATELI, M., 1997. Vertebrados da Ilha de Ratones Grande, Santa Catarina, Brasil. Biot., vol. 10, no. 2, p. 105-122.

GRAIPEL, ME., CHEREM, JJ., MONTEIRO-FILHO, ELA. and GLOCK, L., 2006. Dinâmica populacional de marsupiais e roedores no Parque Municipal da Lagoa do Peri, Ilha de Santa Catarina, sul do Brasil. Mastozool. Neotrop., vol. 13, no. 1, p. 31-49.

GRAIPEL, ME. and SANTOS-FILHO, M., 2006. Reprodução e dinâmica populacional de Didelphis aurita Wied-Neuwied (Mammalia: Didelphimorfia) em ambiente periurbano na Ilha de Santa Catarina, sul do Brasil. Biot., vol. 19, no. 1, p. 65-73.

GRAIPEL, ME., CHEREM, JJ. and XIMENEZ, A., 2001. Mamíferos terrestres não voadores da Ilha de Santa Catarina, sul do Brasil. Biot., vol. 14, no. 2, p. 109-140.

GRANT, PR., 1965. The adaptative significance of some size trends in island birds. Evol., vol. 19, p. 355-367.

HEANY, LR., 1978. Island area and body size of insular mammals: evidence of trio-colored squirrel (Calloscluros prevosti) of Southeast Asia. Evol., vol. 32, p. 29-44.

LAWLOR, TE., 1982. The evolution of body size in mammals: evidence from insular populations in Mexico. Amer. Nat., vol. 119, no. 1, p. 54-72.

LEHMANN, T., 1992. Ectoparasite impacts on Gerbillus andersoni allenbyi under natural conditions. Parasitol., vol. 104, no. 3, p. 479-488.

LINARDI, PM., 2006. Os ectoparasitos de marsupiais brasileiros. In CÁCERES, NC. and MONTEIRO-FILHO, ELA. (Eds.). Os marsupiais do Brasil. Campo Grande: Federal University of Mato Grosso do Sul. p. 37-52.

LOMOLINO, M., 1985. Body size of mammals on island: The Island Rule reexamined. Amer. Nat., vol. 125, no. 2, p. 310-316.

2005. Body size evolution in insular vertebrates: generality of the island rule. Jour. of Biogeo., vol. 32, no. 10, p. 1683-1699.

MEIRI, S., DAYAN, T. and SIMBERLOFF, D., 2004. Body size of insular Carnivores: Little support of the Island Rule. Amer. Nat., vol. 163, no. 3, p. 469-479.

MEIRI, S., DAYAN, T. and SIMBERLOFF, D., 2005. Insular carnivore biogeography: island area and mammalian optimal body size. Amer. Nat., vol. 165, no. 4, p. 505-514.

MILLIEN, V. and DAMUTH, J., 2004. Climate change and size evolution in an island rodent species: new perspective on the Island Rule. Evol., vol. 58, no. 6, p. 1353-1360. 
MONTEIRO-FILHO,ELA., 1987. Biologia reprodutiva e espaço domiciliar de Didelphis albiventris em uma área perturbada na região de Campinas, Estado de São Paulo. Campinas: State University of Campinas. [Master Dissertation].

MONTEIRO-FILHO, ELA. and ABE, S., 1999. Catchability of the withe-ear-opossum, Didelphis albiventris, in a disturbed area of Southern Brazil. Arq. de Ciê. Vet. e Zool., vol. 2, no. 1, p. 31-35.

NAGY, KA. and MILTON, K., 1979. Aspects of dietary quality, nutrient assimilation and water balance in wild wowler monkey (Allouatta palliata). Oeco. (Hist. Arch.), vol. 39, no. 3, p. 249-258.

ROBINSON, JG. and REDFORD, K., 1986. Body size, diet and population density on neotropical forest mammals. Amer. Nat., vol. 128 , no. 5 , p. 665-680.

SALVADOR, CH., CARVALHO-PINTO, C., CARVALHO, R., GRAIPEL, ME. and SIMÕES-LOPES, PC., 2007 Interação parasito-hospedeiro entre ectoparasitos (Ixodida and Siphonaptera) e gambás Didelphis aurita Wied-Neuwied, 1826
(Mammalia: Didelphimorphia), no continente e em ilhas do litoral de Santa Catarina, Sul do Brasil. Biot., vol. 20, no. 4, p. 81-90.

STALLINGS, JR., 1989. Small mammal inventories in an eastern Brazilian Park. Bull. of Flo. Sta. Mus., Biol. Scie., vol. 34, no. 4, p. 153-200.

TELFORD Jr., SR., GONZALEZ, J. and TONN, RJ., 1979. Reproducción y crecimiento de Didelphis marsupialis, un huésped reservorio primario de la enfermedad deChagas en los llanos altos de Venezuela. Bol. de la Direc. de Malariol. y Saneam. Amb., vol. 19, no. 2, p. 44-56.

TYNDALE-BICOE, CH. and MACKENZIE, RB., 1976. Reproduction in Didelphis marsupialis and D. albiventris in Colombia. Jour. of Mammal., vol. 57, no. 2, p. 246-265.

VAN VALEN, L., 1973. Pattern and the balance of nature. Evol,. Theo., vol. 1, p. 31-49.

ZAR, JH., 1999. Biostatical Analysis. 4 ed. New Jersey: Prentice-Hall.

WASSERSUG, RJ., YANG, H., SEPKOSKI, J. and RAUP, D., 1979. The evolution of body size on islands: a computer simulation. Amer. Nat., vol. 114, no. 2, p. 287-295. 
